\title{
Review Article \\ Paleopathological Considerations on Malaria Infection in Korea before the 20th Century
}

\author{
Dong Hoon Shin, ${ }^{1}$ Min Seo, ${ }^{2}$ Jong Ha Hong, ${ }^{1}$ and Eunju Lee $\mathbb{D}^{3}$ \\ ${ }^{1}$ Lab of Bioanthropology, Paleopathology and History of Diseases, Department of Anatomy/Institute of Forensic Science, \\ Seoul National University College of Medicine, Seoul, Republic of Korea \\ ${ }^{2}$ Department of Parasitology, Dankook University, Cheonan, Republic of Korea \\ ${ }^{3}$ Department of Internal Medicine, Asan Medical Center, University of Ulsan College of Medicine, Seoul, Republic of Korea
}

Correspondence should be addressed to Eunju Lee; eunjulee@amc.seoul.kr

Received 28 December 2017; Accepted 1 April 2018; Published 9 May 2018

Academic Editor: Stefano D’Amelio

Copyright (C) 2018 Dong Hoon Shin et al. This is an open access article distributed under the Creative Commons Attribution License, which permits unrestricted use, distribution, and reproduction in any medium, provided the original work is properly cited.

\begin{abstract}
Malaria, one of the deadliest diseases in human history, still infects many people worldwide. Among the species of the genus Plasmodium, P. vivax is commonly found in temperate-zone countries including South Korea. In this article, we first review the history of malarial infection in Korea by means of studies on Joseon documents and the related scientific data on the evolutionary history of P. vivax in Asia. According to the historical records, malarial infection was not unusual in pre-20th-century Korean society. We also found that certain behaviors of the Joseon people might have affected the host-vector-pathogen relationship, which could explain why malarial infection prevalence was so high in Korea at that time. In our review of genetic studies on $P$. vivax, we identified substantial geographic differentiation among continents and even between neighboring countries. Based on these, we were able to formulate a strategy for future analysis of ancient Plasmodium strains in Korea.
\end{abstract}

\section{Introduction}

Globally, malaria is the fifth deadliest disease, infecting approximately 200 million people worldwide [1-3]. Malarial infection is mediated by the arthropod vector Anopheles mosquito. The Plasmodium parasite has a complex life-cycle of sexual reproduction inside the mosquito vector and asexual stage in the vertebrate host. In brief, malarial sporozoites are inoculated into human hosts when a mosquito bites them [4]. After a dormant phase, they differentiate into merozoites for release into the bloodstream, upon which they invade erythrocytes (the beginning of asexual multiplication). The bursting of infected red blood cells (RBCs) by merozoite multiplication is responsible for the typical malarial fever [4]. Some of the merozoites then develop into gametocytes, which are taken up by a female mosquito [4]. Sexual reproduction in the anopheline mosquito is followed by sporozoite migration into the salivary gland, from which they are inoculated into a vertebral host, thus beginning a new cycle of malarial infection [4].
In general, five species of genus Plasmodium are known to cause malaria: P. falciparum, $P$. vivax, P. malariae, $P$. ovale, and $P$. knowlesi [5]. Recent malaria outbreak in Brazil has also been traced to new zoonotic transmission of $P$. simium from monkey [6]. Among them, P. vivax and P. falciparum are the most commonly detected causative pathogens of human malaria. Clinical manifestations of uncomplicated malaria are nonspecific: headache, fever, malaise, myalgia, nausea, vomiting, and abdominal pain. Rare cases of malaria show severe manifestations including anemia, thrombocytopenia, pulmonary edema, renal failure, hepatic dysfunction, and splenic rupture [7].

Although malarial species share typical signs and symptoms such as undulating intermittent fever, they also have different traits depending on each subtype. P. falciparum's symptoms are serious enough to show the highest mortality rate whereas $P$. vivax, $P$. malariae, and $P$. ovale exhibit generally nonfatal clinical courses [5]. The geographical distribution of each Plasmodia subtype differs as well. P. falciparum is more 
prevalent in tropical or subtropical zones including SubSaharan areas but relatively absent in temperate countries [8]. Meanwhile, $P$. vivax generally infects human populations in temperate and tropical zones but is not so prevalent in SubSaharan Africa $[1,3,9]$. P. vivax malaria was endemic even in some high latitude countries (Finland and Russia, etc.) at certain points in history $[4,10,11]$.

As malaria historically has been, and continues to be, one of the most serious diseases, it has attracted the attention of many paleopathologists. Studies on ancient malarial infection have been conducted by various methods such as osteoarchaeological and biomedical approaches [12]. As chronicstage vivax malaria was generally known to induce anemia, further causing porotic hyperostosis (PO) or cribra orbitalia (CO) in the cranium [10], anthropologists have searched for the presence of $\mathrm{PO}$ or $\mathrm{CO}$ in skeletal remains as indirect evidences of malarial infection [5, 12-15]. Nevertheless, PO or CO has clear limitations with respect to its application to the study of ancient malaria because Plasmodium infection is not the only cause of them $[12,16]$. Other pathologies such as inherited hemolytic anemia, scurvy, or malignancies are also known to induce the same skeletal changes of $\mathrm{PO}$ or $\mathrm{CO}$ $[5,12]$.

In recent years, the paleopathological study of malaria has been revolutionized by successful applications of immunological and ancient DNA (aDNA) analyses to archaeological specimens. To detect malaria-related proteins, researchers performed the dipstick assay or new-generation immunoassays on ancient mummies[17-19] or skeletons [20, 21]. The immunological assay became an effective screening method to secure the evidence of ancient malarial infection [5]. Also, Plasmodium aDNAs reportedly have been obtained from Egyptian mummies [2, 22-24], an infant skeleton dating to ancient Rome [25], 15th-to-19th-century infant of Bavaria [26], and 1st-to-2nd-century adult skeletons of Italy [27]. As a paleopathological tool, aDNA analysis is useful for confirming the presence of malarial genomes remnant in archaeological specimens as well as for revealing the origin and dispersal of the protozoan parasite in evolutionary history [28].

Although immunological and molecular analyses have become more reliable tools for the study of ancient malaria, the data obtained to date are not sufficient in terms of quantity and quality [16]. Moreover, since previous studies have focused mainly on ancient Egyptian, Roman, and Renaissance European remains thus far [5], such information as has been obtained from malaria aDNA reflects a serious geographical bias. Extensive geographic sampling is thus necessary in order to understand the demographic history of malaria much more comprehensively and clearly [4, 29-31]. Like the other continents, Asia is also a region where malaria has historically been epidemic and endemic. In several Asian countries, many people continue to have suffered from and even died of Plasmodium infection. Nonetheless, most of the requisite paleopathology still remains to be revealed in Asia as few medical studies on the ancient malaria have been reported in the area. Herein, then, we offer this historical review as a fundamental basis for future research of ancient malaria infection in Korea and other Asian countries.

\section{Origin and Dispersal of Vivax Malaria Parasite}

Parasitologists have speculated that human malaria might have been transmitted from nonhuman primates by a hostswitch event [11]. Initially, they presumed that $P$. falciparum was transmitted from chimpanzees and gorillas in Africa [18] while $P$. vivax originated from another nonhuman primate, possibly macaques, in Southeast Asia [4, 32, 33]. However, this hypothesis is seriously challenged nowadays by the genetic analysis of malaria worldwide. Alternatively, a recent study revealed that both $P$. falciparum and $P$. vivax originated in Africa and that $P$. vivax transmission to human beings might have occurred much earlier than P. falciparum did by a host switch [34].

According to the estimated time to most recent common ancestor (TMRCA), the ancestor of the extant $P$. vivax populations existed between 50 and $550 \mathrm{ka}$ before the present [3]. In a demographic history inferred from the $P$. vivax genome analysis, the global population size of vivax malaria might have expanded slowly until about $60 \mathrm{ka} \mathrm{BP}$, which is closely consistent with the demographic history of mankind $[3,35]$. Once the divergence of African and Eurasian P. vivax populations occurred at about $51 \mathrm{ka} \mathrm{BP}$, the latter appears to have undergone a rapid exponential increase in population size $[3,35]$. Among Eurasian vivax malarias, the East Asian variety might have experienced a distinct pattern of population growth [3]. The population of East Asian variety might have been relatively stable in its expansion until approximately 10,000 years BP [36,37]. It then began to increase rapidly once rice and millet started to be domesticated in the area and sustained such increase, without tapering off, until the present [3]. The inferred hypothesis is suggestive of the detailed evolutionary history of vivax malaria in East Asia [3].

In the phylogenetic tree of $P$. vivax worldwide, two divergent groups were identified: a large star-like cluster and a divergent cluster [3]. The latter was composed of two subclades with different geographical distributions: "Asia a" of Central China and "Asia $b$ " of China, Korea, and Indonesia. The divergent East Asian P. vivax lineage was connected to the large star-like cluster by a group of haplotypes found in Southeast Asia [3]. Based on the phylogenetic analysis, East Asian $P$. vivax might have been split from all other vivax malaria and developed a distinct demographic history for at least $121 \mathrm{ka}$ [3]. Meanwhile, mutations of $P$. vivax-resistant RBCs (Duffy-negative phenotype) occurred in Sub-Saharan peoples [38]. Due to the mutations, vivax malaria disappeared completely from the area until the reintroduction of $P$. vivax to East Africa by sea-going traders from Asia [39].

\section{History of Malaria Infection in Korea}

The historical record is important for understanding the pattern of malarial infection in ancient civilizations[27]. In the classical period of Greece, Hippocrates famously described the typical undulating fever, a very suggestive sign of malarial infection $[5,39]$. Historians believed that malaria became hyperendemic in Europe by its spread around the Mediterranean area, next along the riverbanks of the Rhine, 
Danube, and Rhone and then further to Northern Europe, while accommodating to colder climatic conditions in those areas [40]. Historical studies have shown that malaria became remarkably prevalent in the marshy areas of Northern Europe in the Early Middle Ages [5, 40, 41]. By the Later Middle to Early Modern Ages, except for Iceland, plenty of reports on malaria were available from every corner of Europe (including the North Sea, Germany, Anglo-Saxon England, and even Scandinavian countries) [40, 42, 43]. In a sense, malaria appears to have been a much more serious disease than even the Plague [40, 44].

Malaria must have been endemic in East Asia from ancient times as well, as descriptions about malaria-like symptoms can be seen in Chinese historical records [45]. Although Korea had been in close interaction with China from earliest times, in Korean history, the first recorded case of malaria occurred only in the Goryeo Dynasty (918-1392 CE) [46]. In a 14th-century record, a Joseon King's mother (Joseon Dynasty: 1392-1910 CE) was seriously infected with malaria and eventually died of it [47]. Over the following centuries, a wealth of records on the typical signs and symptoms of malarial infection (intermittent fever, repeated every third day) can be found in the Korean historical literature [47]. As most malarial infection in modern Korea has been revealed to have been caused by P. vivax [48], the Joseon people might have suffered from the same Plasmodium subtype. Notwithstanding the benign traits of $P$. vivax, relapsed infection typically might have exhausted people, often eventually killing them, as seen in similar clinical reports today [3, 49-53].

Before the first modern medical record on malaria in Korea (1886), prevalences of malarial infection could not be reliably calculated. In the First Annual Report of the Korean Government Hospital, Seoul, Dr. Horace Newton Allen described "endemic intermittent fever" (possibly malaria) as the most commonly observed sign among Korean patients who visited his hospital $[54,55]$. According to him, in the late 19th century, hyperendemic malaria posed a serious threat to Koreans throughout the entire Joseon Kingdom. How, exactly, did malaria show such a high infection prevalence in Joseon society? In general, wetlands such as scattered swamps, bogs, and river valleys have been important habitats for anopheline mosquito breeding. As wetlands were distributed widely in Korea at that time, they must have been integral to the high malarial transmission rates $[34,40,56-$ 63].

In malariology, however, the waxing and waning of malarial infection in a specific area cannot be explained so simply. In addition to wetlands, environmental alteration or degradation due to human activity also has a great influence on the density and activity of mosquito populations and, further, on the prevalence of malaria itself[64-66]. Table 1 summarizes the anthropogenic causes of malaria currently recognized by scholars. As is apparent, people's efforts to exploit environments often induce outbreaks of malaria [40, $60,64,67]$. Indeed, agricultural development and malaria are highly correlated in human history [60, 68-72]. The expansion of irrigation facilities, the reclamation of wetlands, economic specialization in agriculture, the simplification of crop types, enlargements of rice paddies, high population densities, deforestation, and still other malaria-inducing factors have been commonly cited (Table 1).

We do not yet know whether the close relationship between environmental change by agriculture and malarial infection is a universal phenomenon beyond certain temporal and spatial limits. In a recent cross-national analysis, however, correlations among anthropogenic activity, mosquito population sizes, and malaria rates were seen to have been common in many parts of the world [64]. The findings of Table 1 can thus be applied to our conjecture about Joseon society's vulnerability to malarial infection. In our careful examination of the Joseon records, we found many similar malarial-infection-facilitating situations to those noted in Table 1. The situations in Joseon society are summarized in Table 2.

In brief, the 15th to 19th centuries in Korean history were a turbulent and dynamic period during which the Joseon people were highly motivated to be involved in agricultural innovation, thereby eventually effecting major changes in their sociocultural environment (Table 2). By infusion of labor and capital investments into land development, the state of the agricultural techniques was advanced. By clearing every corner of wasteland and reclaiming wetlands, huge areas of farmland in the Kingdom were newly opened up [73-77]. Farmers cleared slash-and-burn fields even up to the tops of mountains $[63,73,76]$. By the end of the Joseon Dynasty, there was virtually no land remaining that had not been utilized for farming purposes (Table 2).

On such lands, Joseon farmers planted crops. Rice was very popular, becoming the most preferred crop by the late Joseon Dynasty [73]. To meet growing market demand for rice, farmers hastily turned their existing dry fields into rice paddies [54, 63, 73-75, 78, 79]. To supply enough water for rice cultivation, irrigation systems comprised of reservoirs and dammed pools were newly constructed in the Kingdom [54, 63, 74, 75, 78, 80]. Due to such increased agricultural productivity during the 15th to 19th centuries, the population of the Joseon Kingdom soared [73, 76]. All of these changes meant that the Joseon people came to live more and more in highly populated villages, towns, and cities around which rice paddies, reservoirs, and dams were scattered (Table 2). Certainly, as long as this new situation continued, malarial prevalence was by no means lowered. In a sense, intensive farming appears to have been a necessary evil for the Joseon people, as, notwithstanding the malaria-inductive environments thus created, the increased food production potentiated and achieved thereby was a great economic as well as social boon to the Kingdom.

From the late 19th century, the diagnosis and treatment of malaria began to be performed by specialists in Western medicine. In 1913, for example, an intermittent fever observed among Korean patients was finally confirmed by a modern microbiology technique to be Plasmodium infection [54, 81]. During the Japanese colonial period, however, significant reduction of malarial incidence proved difficult, as the environmental conditions associated with agriculture remained the same. Since the end of World War II and subsequent US army administration, malarial infection as well as its 


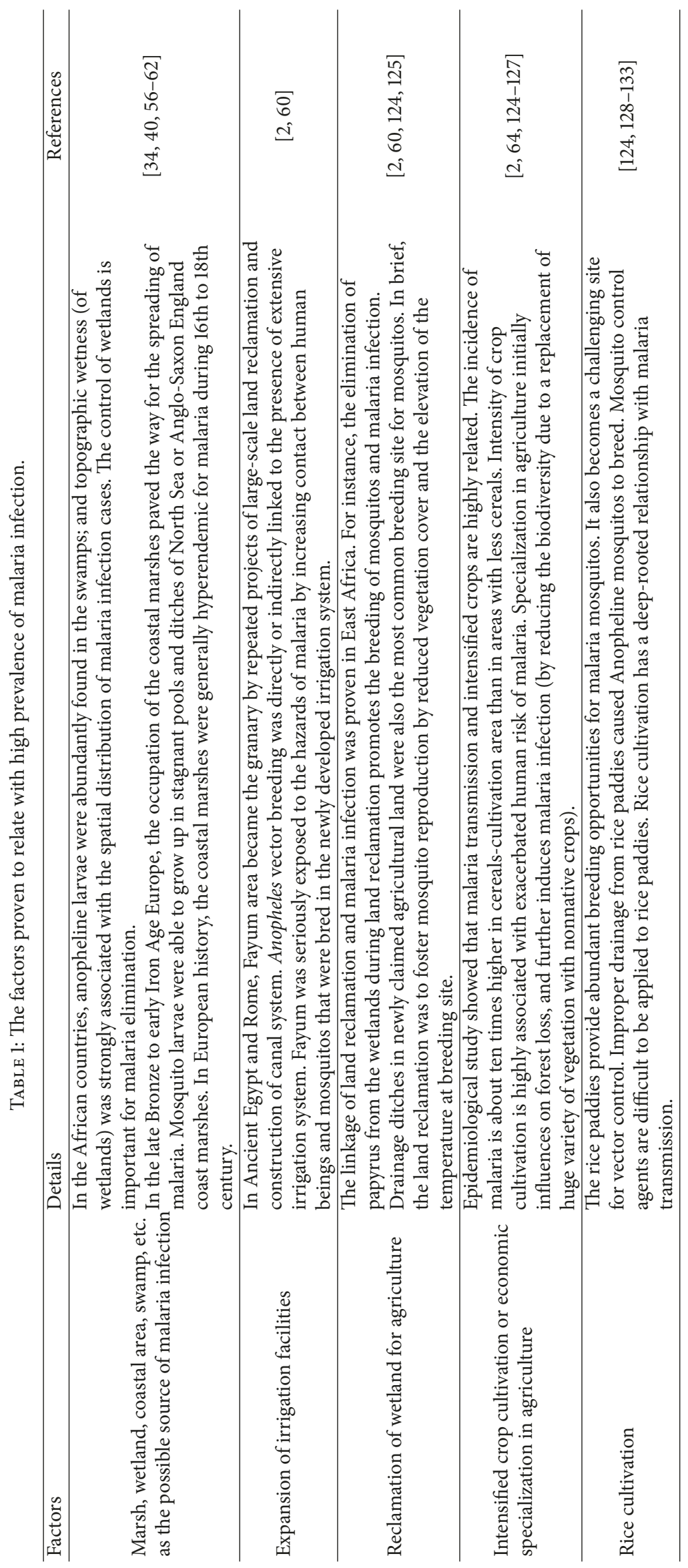




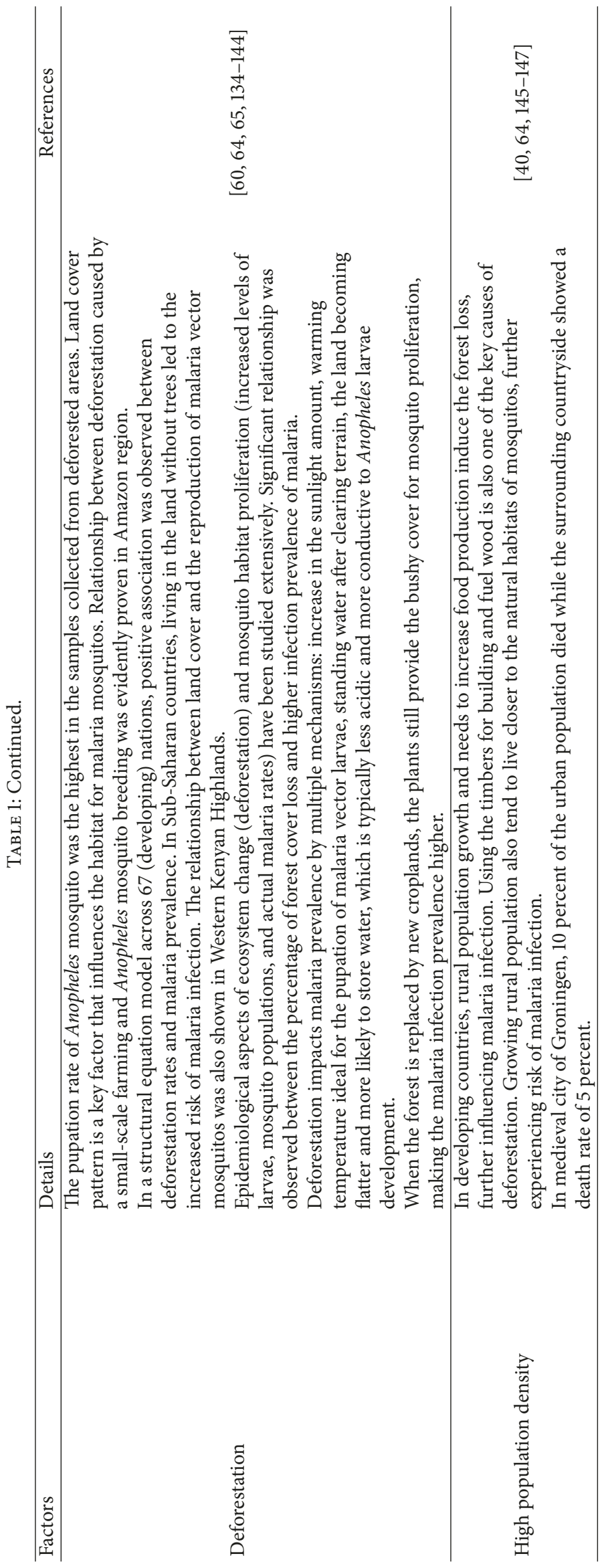




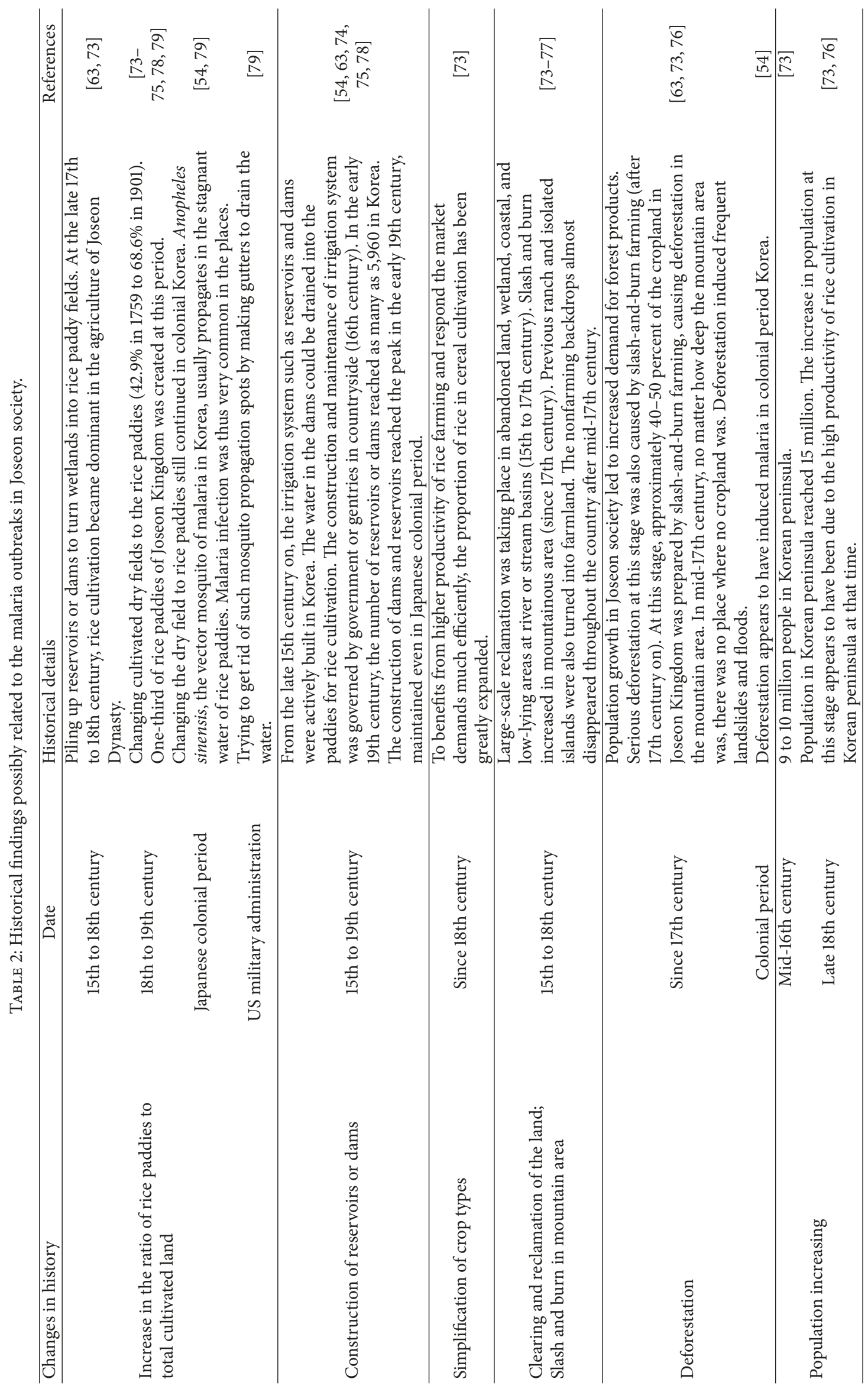


management underwent a revolutionary change in Korea. The US army, which had experienced many deaths from malaria in the course of the war with Japan, was able to establish an effective means of controlling the Plasmodium infection in Asia [79]. Whereas the Japanese during the period of their colonial rule of Korea preferred a strategy entailing curing of malaria patients by quinine treatment at the onset of the disease, the US military administration adopted a far more aggressive and highly effective policy of controlling malaria through the use of insecticides [79].

However, we must also consider the possibility that malarial prevalence in the country was not reduced by antimalarial medications or insecticides alone. This idea is supported by instances in European history. In the 18th to 19th centuries, malaria was still prevalent in Europe, though it rapidly declined thereafter, finally disappearing from most regions by the 1930s [82]. The retreat of malaria from Europe was not the result of medical or chemical innovations, as no such deliberate countermeasures (entailing use of quinine or insecticide, etc.) had been pursued at that time [83]. Rather, another factor has been proposed to explain the decline of malaria in Europe: socioeconomic progress [84]. Many studies in fact have shown a positive correlation between malaria and poverty $[85,86]$. Furthermore, it has been established that malaria was active for much longer periods of time in regions where modernization was delayed [40]. In Finland, long-term social changes such as land consolidation, decreasing household size, fewer interactions between families, and the transition from extended family to nuclear family have been posited as causes of malaria's decline during the past 200 years [83]. In fact, the combined effects of social innovations and improved standards of living were decisive in controlling and eventually eradicating malaria in Europe [40, 60]. Arguably, this explanation is applicable to the decline of malaria in South Korea as well. In that country, malaria was eradicated in the 1970s by the cooperative efforts of the World Health Organization (WHO) and Korea's National Malaria Eradication Program $[48,87]$. Significantly, this corresponded to the period of rapid industrialization by which the living standards of the Korean people were remarkably improved. In short, socioeconomic development in South Korea might have made a great contribution to the eradication of malaria in that country.

Unfortunately, the reemergence of malaria after longterm eradication is not a rare phenomenon in the world[3, 88]. In 1993, after more than two decades of malaria-free status, a new Korean malaria patient was reported among soldiers who had served near the Demilitarized Zone (DMZ) in South Korea [48, 89]. At the time, as North Korea was suffering malarial infection, the new patient was thought to have been infected by an Anopheles mosquito migrating from the north $[87,90]$. In fact, this cannot explain everything about the reemergence of malaria in South Korea, as, nowadays at least, foreign travelers and workers from malaria-endemic regions are commonplace [87]. Today, malaria is once again an endemic disease and a source of public concern in South Korea, as cases of malarial infection have continued to be reported [87, 90, 91].

\section{Genetic Diversity of Modern Korean $P$. vivax Isolates}

Malarial infection in history often cannot be fully evidenced by the examination of historical documents. This is due to difficulty in accurate diagnosis of ancient malaria cases in history. Actually, the signs and symptoms of ancient malaria patients were often vaguely described in historical literatures by modern clinical medicine standards. In addition, diagnosis of ancient malaria (solely) by the examination of archaeologically obtained skeletal remains is also highly problematic as malaria leaves little traces on bones. In this regard, we note that DNA-based study could be useful for acquiring scientific evidences of specific diseases prevalent in history[27].

DNA analysis of $P$ vivax is generally targeted on the protozoan parasites' surface proteins by which the erythrocyte invasion of the vivax-malarial parasite can be triggered $[92,93]$. One such surface protein is the $P$. vivax merozoite surface protein (PvMSP), which is abundantly expressed on the merozoites of vivax malaria [94]. Duffy-binding protein $(\mathrm{PvDBP})$ is another membrane protein that is also present on the $P$. vivax merozoites and that plays a crucial role in RBC invasion of parasites [92, 93, 95, 96]. As antibodies against these proteins effectively block the invasion of $P$. vivax into human RBC[91], PvMSP and PvDBP are regarded as leading candidates for use in the development of malaria vaccines [91, 97-99] though great genetic diversity among those surface proteins still represent a major obstacle to the vaccine research $[4,91,97,100-103]$.

Since the reemergence of $P$. vivax in South Korea [48, 87], Korean researchers also have aimed to study the genetic traits of vivax malaria's PvMSP, PvDBP, circumsprozoite protein (PvCSP), apical membrane antigen-1 (AMA-1), microsatellites sequences, and $18 \mathrm{~S}$ ribosomal RNA genes [87, 90, 91, 103108]. Those scientists are indeed eager to analyze the genetic diversity, population structure, and operation of natural selection among Korean $P$. vivax isolates, as the outcomes would doubtlessly be useful for understanding the nature of the $P$. vivax population in South Korea [90, 91, 97]. In general, the genetic diversity of $P$. vivax is higher than that of $P$. falciparum, suggesting that the former has a long, complex, but successful evolutionary history of adaptation [4, 109112]. However, when P. vivax reemerged in South Korea, the isolates of the years 1993 to 2000 were genetically closely related, meaning that its genetic diversity was very low at the initial stage of its reintroduction [113]. Since 2001, the reemergent malaria population in South Korea has become more heterogeneous, showing increased genetic diversity and a more complex population structure $[87,89,97,108]$. The results clearly indicate that some genotypes that were not found before 2000 eventually migrated into South Korea at a much later date, as accompanied by outbreeding between different genotypes [90].

Ju et al. [91] also reported that a phylogenetic analysis based on PvDBPII sequences showed 3 different clusters (SK$1, \mathrm{SK}-2$, and SK-3) in Korean P. vivax isolates. Among them, SK-3 was a new clade that had not been identified at the early phase of reemergence in the same Korean isolates [106] but later became a more prevalent group than either SK-1 or 


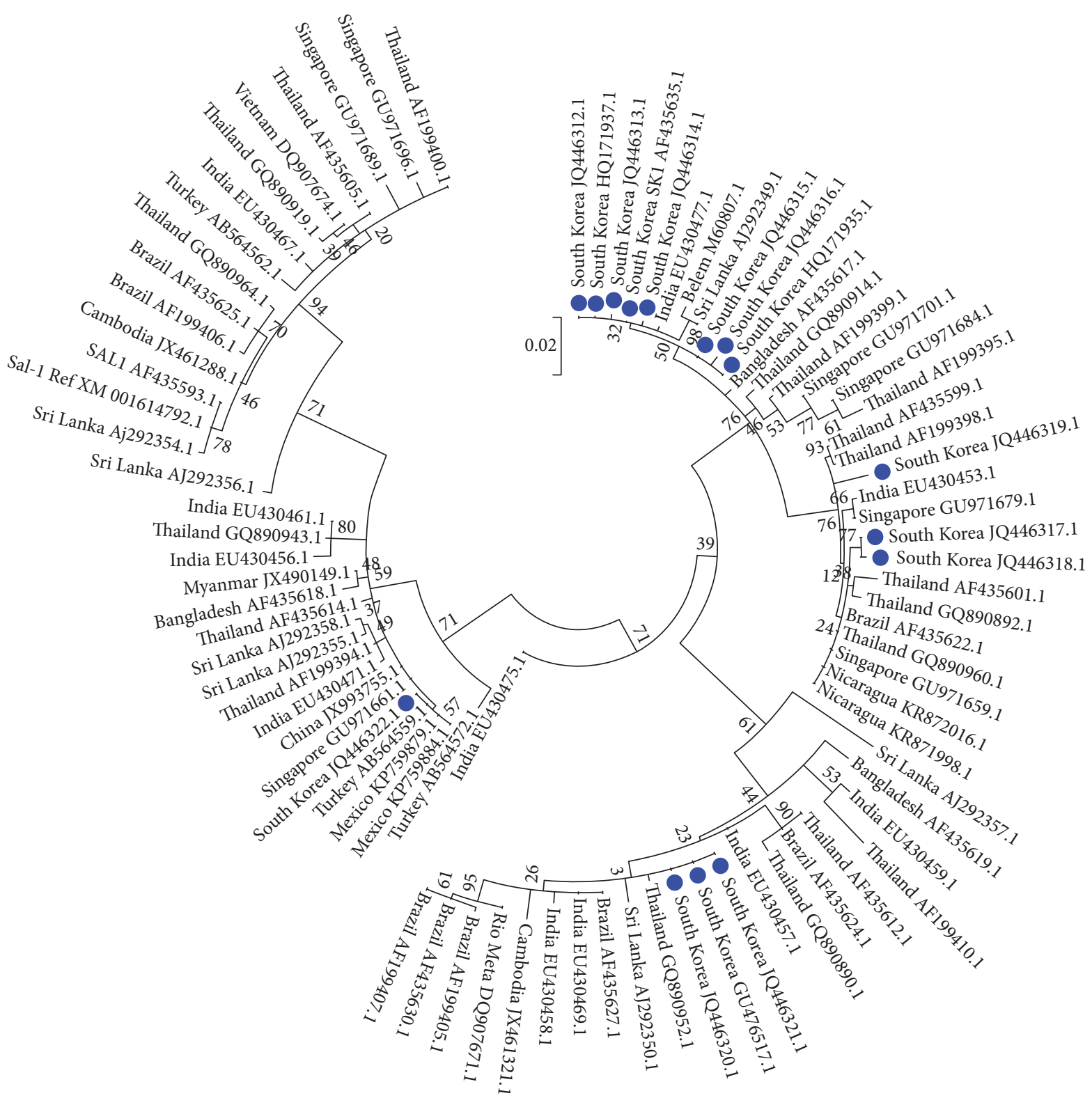

Figure 1: Maximum Likelihood (ML) tree of Plasmodium vivax MSP-1 $1_{42}$ gene sequences reflecting the genetic traits of South Korean isolates (blue dots) since the reemergence of $P$. vivax in 1993. We inferred the ML tree by MEGA6 program [114], based on the research result of Kang et al. [97]. Tree building also used additional MSP-1 $1_{42}$ gene sequences $(n=18)$ collected from GenBank: South Korea (GU476517.1; HQ171935.1; HQ171937.1), Bangladesh (AF435619.1), Brazil (AF435625.1; AF435627.1; AF435630.1), Cambodia (JX461288.1; JX461321.1), China (JX993755.1), Mexico (KP759879.1; KP759884.1), Myanmar (JX490149.1), Nicaragua (KR871998.1; KR872016.1), Rio Meta (DQ907671.1), and Thailand (AF435599.1; AF435605.1). Bootstrap values were made for ML tree [115]; the number in the branches indicates bootstrap proportions (1,000 replicates). Scale is in substitutions per variable site. Support values were calculated using Hasegawa-Kishino-Yano model. In this tree,

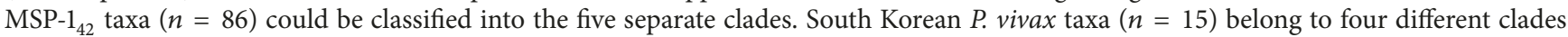
among them. Half of them were essentially similar to the Belem type; the others were recombinant forms between Sal-1 and Belem.

SK-2 [91]. They agreed that the polymorphic nature of the PvDBPII of recent malarial isolates is distinct from those isolated at the early phase of malaria's reemergence in South Korea. The value in the rate of nonsynonymous and synonymous mutations ( $\mathrm{dN}-\mathrm{dS})$ also implied that PvMSP in Korean $P$. vivax isolates has been under the strong influence of positive natural selection [97] (Figure 1).

\section{Paleopathological Approach to Ancient Malaria Infection in Korea}

The recent studies on genetic diversity, gene flow, and population structure are also very significant to the development of strategic control measures against vivax malaria after its reemergence in South Korea [90, 112, 116]. Despite all the 
TABLE 3: Archaeological information on mummy samples with liver obtained during autopsy.

\begin{tabular}{|c|c|c|c|c|}
\hline Number & Mummy & Estimated Date & Sex & $\begin{array}{c}\text { Date of excavation } \\
\text { (YYYY.MM) }\end{array}$ \\
\hline 1 & Cheongdo & $1642^{\mathrm{a}}$ & Male & 2014.10 \\
\hline 2 & Andong & $18 C^{b}$ & Male & 2013.01 \\
\hline 3 & Dalsung & $16 C-17 C^{c}$ & Female & 2014.05 . \\
\hline 4 & Hwasung & $18 \mathrm{C}^{\mathrm{c}}$ & Male & 2012.12 \\
\hline 5 & Gangneung & $1622^{\mathrm{a}}$ & Male & 2007.11. \\
\hline 6 & Hadong2 & Late 16 -early $17 C^{a}$ & Female & 2009.06 \\
\hline 7 & Kunkook & Joseon period ${ }^{c}$ & Female & Unknown \\
\hline 8 & Mungyeong & $1647^{\mathrm{d}}$ & Female & 2010.04 \\
\hline
\end{tabular}

${ }^{\mathrm{a}}$ Historical documentation. ${ }^{\mathrm{b}}$ Carbon dating. ${ }^{\mathrm{c}}$ Archaeological evidence. ${ }^{\mathrm{d}}$ Tree ring.

benefits, however, the overall genetic trends of vivax malaria, especially concerning its evolutionary history, have not yet been revealed by the simple genomic assay of modern isolates. In fact, the investigation of $P$. vivax using presentday DNA extracts from modern Korean isolates often leads to confusion as to vivax malaria's origin and dispersal [28]. To overcome this drawback, we must conduct aDNA analyses on various human samples obtained from archaeological sites in Korea to analyze the genetic origin and phylogenetic history of malaria more accurately and comprehensively.

The significance of aDNA analysis to any derived understanding of the evolutionary history of malaria recently has been demonstrated by Gelabert et al. [28]. By way of aDNA analysis on 70-year-old microscopic slides of blood from malaria-infected people in Spain, they were able to successfully reconstruct the mtDNA sequence of the now-eradicated European $P$. vivax malaria. Moreover, as it was proven to be related to the most common present-day American $P$. vivax haplotype, the authors were able to confirm that vivax malaria entered the Americas by post-Columbian contact with Europeans [28]. In this way, aDNA assay of ancient human remains can be used for finding the missing links in the origin and spread of ancient malaria.

In aDNA analysis, the types of specimens to choose are very crucial to the research's success. To select the specimens ideal for aDNA assay purposes, the life-cycle of the vivax-malarial parasite must be considered. In brief, when malarial sporozoites are inoculated into human hosts, some of them migrate to the liver wherein they invade the hepatic parenchymal cells [4]. While some sporozoites can maintain the dormant state there, they can be further differentiated into merozoites and released into the bloodstream [4]. As seen in vivax malaria's life-cycle, the liver is the place where the final preerythrocytic phase takes place [45]. In this regard, Joseon Dynasty (1392-1910 CE) mummy's livers might be significant to our project. For the past 10 years, scientists and archaeologists in South Korea have been involved in interdisciplinary work on well-preserved mummies discovered in Joseon Dynasty tombs [117-123]. The livers that could be used for aDNA analysis were obtained from mummies by en bloc resection during autopsy (Table 3) [117].
Nevertheless, as the number of malaria sporozoites at liver stage might be actually very small, we should also consider alternate specimens for our aDNA analysis. In this regard, we note that a small amount (less than $1 \mathrm{~g}$ ) of spongy bones inside vertebrae (possibly containing hemopoietic cell remains) was chosen commonly as specimens for aDNA analysis of malaria; and in another case, first or second molars have been selected for Plasmodium aDNA analysis [27]. Many future studies on ancient malarial genomes will proceed with these specimens of Korean mummies or skeletons.

\section{Conclusion}

With respect to human samples obtained from archaeological sites, scientific techniques can be done to reveal whether the individual had suffered from malaria in his lifetime or to obtain phylogenetic information of its ancient genome. As the previous studies on ancient malaria have focused mainly on specimens from Egypt and Europe, however, the current information so far obtained carries a serious geographical bias. More extensive geographic samplings and assays are thus needed in order to obtain a more comprehensive demographic evolutionary history of malaria.

Like the other continents, Asia is a region wherein malarial infection has been epidemic in history. Nonetheless, very little has been done in the way of relevant paleopathological studies on ancient malaria. We thus reviewed the history of malaria in Korea and attempted to derive scientific clues to the evolution of $P$. vivax there and elsewhere in Asia. To those ends, we first examined the historical-documentary evidence of ancient malarial outbreaks in Joseon society and found that malarial epidemics were in fact not unusual in pre-20th-century Korea. We detected changes in the hostvector-pathogen relationship, which probably affected the proliferation of the mosquito vector and indeed the prevalence of ancient malaria in Joseon society. We also noted, in our review of genomic studies on $P$. vivax, substantial geographic differentiation of vivax-malarial DNA between different continents and even neighboring countries. Many scientific studies on the history of malaria will be done with ancient specimens in Korea and Asia, pending the permission of the relevant medical-ethics review boards. 


\section{Conflicts of Interest}

The authors declare that there are no conflicts of interest regarding the publication of this paper.

\section{Authors' Contributions}

Dong Hoon Shin and Min Seo contributed equally to this study as first authors.

\section{Acknowledgments}

This work was supported by the National Research Foundation of Korea (NRF) grant funded by the Korea government (MSIP) (NRF-2016R1A2B4015669). The authors specially thank Dr. Min Jae Kim (Department of Infectious Diseases, Asan Medical Center, South Korea), for his great advice with regard to our manuscript.

\section{References}

[1] World Health Organization, World malaria report 2011, World Health Organization, Geneva, Switzerland, 2011.

[2] A. Lalremruata, M. Ball, R. Bianucci et al., "Molecular identification of Falciparum malaria and human tuberculosis coinfections in mummies from the Fayum Depression (Lower Egypt)," PLoS ONE, vol. 8, no. 4, Article ID e60307, 2013.

[3] J. E. Taylor, M. A. Pacheco, D. J. Bacon et al., "The evolutionary history of plasmodium vivax as inferred from mitochondrial genomes: Parasite genetic diversity in the Americas," Molecular Biology and Evolution, vol. 30, no. 9, pp. 2050-2064, 2013.

[4] O. E. Cornejo and A. A. Escalante, "The origin and age of Plasmodium vivax," Trends in Parasitology, vol. 22, no. 12, pp. 558563, 2006.

[5] A. Nerlich, "Paleopathology and paleomicrobiology of malaria," Microbiology Spectrum, vol. 4, no. 6, Article ID PoH-0006-2015, 2016.

[6] P. Brasil, M. G. Zalis, A. de Pina-Costa et al., "Outbreak of human malaria caused by Plasmodium simium in the Atlantic Forest in Rio de Janeiro: A molecular epidemiological investigation," The Lancet Global Health, 2017.

[7] World Health Organization, Guidelines for the Treatment of Malaria, World Health Organization, Geneva, Switzweland, 3rd edition, 2015.

[8] R. Carter and K. N. Mendis, "Evolutionary and historical aspects of the burden of malaria," Clinical Microbiology Reviews, vol. 15, no. 4, pp. 564-594, 2002.

[9] M. Miao, Z. Yang, H. Patch, Y. Huang, A. A. Escalante, and L. Cui, "Plasmodium vivax populations revisited: Mitochondrial genomes of temperate strains in Asia suggest ancient population expansion," BMC Evolutionary Biology, vol. 12, no. 1, article no. 22, 2012.

[10] L. Huldén, L. Huldén, and K. Heliövaara, "Endemic malaria: An 'indoor' disease in northern Europe. Historical data analysed," Malaria Journal, vol. 4, no. 19, 2005.

[11] R. Culleton, C. Coban, F. Y. Zeyrek et al., "The origins of african plasmodium vivax; insights from mitochondrial genome sequencing," PLoS ONE, vol. 6, no. 12, Article ID e29137, 2011.

[12] T. J. Setzer, "Malaria detection in the field of paleopathology: A meta-analysis of the state of the art," Acta Tropica, vol. 140, pp. 97-104, 2014.
[13] M. N. Cohen, Health and the Rise of Civilization, Yale University Press, New Haven, CT, 1989.

[14] T. D. White and P. A. Folkens, Human Osteology, Academic Press, San Diego, 2000.

[15] T. D. White and P. A. Folkens, The Human Bone Manual, Elsevier Academic, Amsterdam, Boston, 2005.

[16] R. Bianucci, A. Araujo, C. M. Pusch, and A. G. Nerlich, "The identification of malaria in paleopathology-An in-depth assessment of the strategies to detect malaria in ancient remains," Acta Tropica, vol. 152, pp. 176-180, 2015.

[17] R. L. Miller, S. Ikram, G. J. Armelagoss et al., "Diagnosis of Plasmodium falciparum infections in mummies using the rapid manual ParaSightTM-F test," Transactions of the Royal Society of Tropical Medicine and Hygiene, vol. 88, no. 1, pp. 31-32, 1994.

[18] E. Rabino Massa, N. Cerutti, A. Marin et al., "Malaria in ancient Egypt: paleoimmunological investigations in predynastic mummified remains," Chungara, vol. 32, no. 1, pp. 7-9, 2000.

[19] R. Bianucci, G. Mattutino, R. Lallo et al., "Immunological evidence of Plasmodium falciparum infection in an Egyptian child mummy from the early dynastic period," Journal of Archaeological Science, vol. 35, no. 7, pp. 1880-1885, 2008.

[20] G. Fornaciari, V. Giuffra, E. Ferroglio, and R. Bianucci, "Malaria Was "the Killer" of Francesco I de' Medici (1531-1587)," American Journal of Medicine, vol. 123, no. 6, pp. 568-569, 2010.

[21] G. Fornaciari, V. Giuffra, E. Ferroglio, S. Gino, and R. Bianucci, "Plasmodium falciparum immunodetection in bone remains of members of the Renaissance Medici family (Florence, Italy, sixteenth century)," Transactions of the Royal Society of Tropical Medicine and Hygiene, vol. 104, no. 9, pp. 583-587, 2010.

[22] A. G. Nerlich, B. Schraut, S. Dittrich, T. Jelinek, and A. R. Zink, "Plasmodium falciparum in ancient Egypt," Emerging Infectious Diseases, vol. 14, no. 8, pp. 1317-1319, 2008.

[23] Z. Hawass, Y. Z. Gad, S. Ismail et al., "Ancestry and pathology in King Tutankhamun's family," The Journal of the American Medical Association, vol. 303, no. 7, pp. 638-647, 2010.

[24] R. Khairat, M. Ball, C.-C. H. Chang et al., "First insights into the metagenome of Egyptian mummies using next-generation sequencing," Journal of Applied Genetics, vol. 54, no. 3, pp. 309325, 2013.

[25] R. Sallares and S. Gomzi, "Biomolecular archaeology of malaria," Ancient Biomolecules, vol. 3, pp. 195-213, 2001.

[26] A. Zink, C. J. Haas, K. Herberth, and A. G. Nerlich, "PCR amplification of Plasmodium DNA in ancient human remains," Ancient Biomolecules, vol. 3, p. 293, 2001.

[27] S. Marciniak, T. L. Prowse, D. A. Herring et al., "Plasmodium falciparum malaria in 1st-2nd century CE southern Italy," Current Biology, vol. 26, no. 23, pp. R1220-R1222, 2016.

[28] P. Gelabert, M. Sandoval-Velasco, I. Olalde et al., "Mitochondrial DNA from the eradicated European Plasmodium vivax and P. falciparum from 70-year-old slides from the Ebro Delta in Spain," Proceedings of the National Acadamy of Sciences of the United States of America, vol. 113, no. 41, pp. 11495-11500, 2016.

[29] M. F. Hammer, F. Blackmer, D. Garrigan, M. W. Nachman, and J. A. Wilder, "Human population structure and its effects on sampling Y chromosome sequence variation," Genetics, vol. 164, no. 4, pp. 1495-1509, 2003.

[30] L. Excoffier, "Patterns of DNA sequence diversity and genetic structure after a range expansion: lessons from the infiniteisland model," Molecular Ecology, vol. 13, no. 4, pp. 853-864, 2004. 
[31] M. Imwong, D. Sudimack, S. Pukrittayakamee et al., "Microsatellite variation, repeat array length, and population history of Plasmodium vivax," Molecular Biology and Evolution, vol. 23, no. 5, pp. 1016-1018, 2006.

[32] A. A. Escalante, O. E. Cornejo, D. E. Freeland et al., "A monkey's tale: The origin of Plasmodium vivax as a human malaria parasite," Proceedings of the National Acadamy of Sciences of the United States of America, vol. 102, no. 6, pp. 1980-1985, 2005.

[33] J. Mu, D. A. Joy, J. Duan et al., "Host switch leads to emergence of Plasmodium vivax malaria in humans," Molecular Biology and Evolution, vol. 22, no. 8, pp. 1686-1693, 2005.

[34] D. E. Loy, W. Liu, Y. Li et al., "Out of Africa: origins and evolution of the human malaria parasites Plasmodium falciparum and Plasmodium vivax," International Journal for Parasitology, vol. 47, no. 2-3, pp. 87-97, 2017.

[35] S. Gravel, B. M. Henn, R. N. Gutenkunst et al., "Demographic history and rare allele sharing among human populations," Proceedings of the National Acadamy of Sciences of the United States of America, vol. 108, no. 29, pp. 11983-11988, 2011.

[36] H. Lu, J. Zhang, and K.-B. Liu, "Earliest domestication of common millet (Panicum miliaceum) in East Asia extended to 10,000 years ago," Proceedings of the National Acadamy of Sciences of the United States of America, vol. 106, no. 18, pp. 73677372, 2009.

[37] J. Molina, M. Sikora, N. Garud et al., "Molecular evidence for a single evolutionary origin of domesticated rice," Proceedings of the National Acadamy of Sciences of the United States of America, vol. 108, no. 20, pp. 8351-8356, 2011.

[38] L. L. Cavalli-Sforza, P. Menozzi, and A. Piazza, The History and Geography of Human Genes, Princeton University Press, Princeton, New Jersey, USA, 1994.

[39] M. D. Bogdonoff, J. K. Crellin, R. A. Good et al., The Genuine Works of Hippocrates, Classics of Medicine Library, Birmingham, UK, 1985.

[40] O. S. Knottnerus, "Malaria Around the North Sea: A Survey," in in proceedings of Climatic Development and History of the North Atlantic Realm: Hanse Conference Report, G. Wefer, W. H. Berger, K. E. Behre, and E. Jansen, Eds., pp. 339-353, SpringerVerlag, Berlin Heidelberg, 2002.

[41] O. S. Knottnerus, "Malaria in den Nordseemarschen: Gedanken über Mensch und Umwelt," in Dünger und Dynamit: Beiträge zur Umweltgeschichte Schleswig-Holsteins und Dänemarks, M. Jakubowski-Tiessen and K. J. Lorenzen-Schmidt, Eds., pp. 2539, Neumünster, 1999.

[42] E. Meineke and K. Schier, "Fieber," in Reallexikon der germanischen Altertumskunde, J. Hoops and H. Jankuhn, Eds., vol. 9, pp. 4-11, De Gruyter, Berlin, 2nd edition, 1995.

[43] V. Møller-Christensen, "Feber," in Kulturhistorisk leksikon for nordisk middelalder fra vikingetid til reformationstid, vol. 4, pp. 208-210, København, Rosenkilde og Bagger, Kopenhagen Oslo Malmö, 1959.

[44] G. Keil, "Malaria," in Lexikon des Mittelalters, R. Auty et al., Ed., vol. 6, pp. 162-163, Munich, Artemis, 1993.

[45] F. E. Cox, "History of the discovery of the malaria parasites and their vectors," Parasites \& Vectors, vol. 3, no. 1, article 5, 2010.

[46] H. S. Lee, "Goryeo Period," in Hangukjeonyeombyueongsa, K. W. Choi et al., Ed., pp. 65-108, The Korean Society of Infectious Diseases, Gunjachulpansa, Seoul, South Korea, 2009.

[47] S. S. Kim, "The first half of Joseon Period," in Hangukjeonyeombyueongsa, K. W. Choi et al., Ed., pp. 113-200, The Korean Society of Infectious Diseases, Gunjachulpansa, Seoul, South Korea, 2009.
[48] I. H. Chai, G. I. Lim, S. N. Yoon, W. I. Oh, S. J. Kim, and J. Y. Chai, "Occurrence of tertian malaria in a male patient who has never been abroad," The Korean Journal of Parasitology, vol. 32, no. 3, pp. 195-200, 1994.

[49] D. K. Kochar, V. Saxena, N. Singh, S. K. Kochar, S. V. Kumar, and A. Das, "Plasmodium vivax malaria," Emerging Infectious Diseases, vol. 11, no. 1, pp. 132-134, 2005.

[50] N. M. Anstey, T. Handojo, and M. C. F. Pain, "Lung injury in vivax malaria: pathophysiological evidence for pulmonary vascular sequestration and posttreatment alveolar-capillary inflammation," The Journal of Infectious Diseases, vol. 195, no. 4, pp. 589-596, 2007.

[51] M. A. Alexandre, C. O. Ferreira, A. M. Siqueira et al., "Severe Plasmodium vivax malaria, Brazilian Amazon," Emerging Infectious Diseases, vol. 16, no. 10, pp. 1611-1614, 2010.

[52] N. M. Douglas, N. M. Anstey, P. A. Buffet et al., "The anaemia of Plasmodium vivax malaria," Malaria Journal, vol. 11, article 135, 2012.

[53] V. B. Kute, H. L. Trivedi, A. V. Vanikar et al., "Plasmodium vivax malaria-associated acute kidney injury, India, 2010-2011," Emerging Infectious Diseases, vol. 18, no. 5, pp. 842-845, 2012.

[54] I. Yeo, “A history of malaria in modern Korea 1876-1945," Korean Journal of Medical History, vol. 20, no. 1, pp. 53-82, 2011.

[55] I. Yeo, Allen eui euiryo bogoseo, Yeoksagonggan, Seoul, 2016.

[56] J. M. Chase and T. M. Knight, "Drought-induced mosquito outbreaks in wetlands," Ecology Letters, vol. 6, no. 11, pp. 10171024, 2003.

[57] J. M. Cohen, K. C. Ernst, K. A. Lindblade, J. M. Vulule, C. C. John, and M. L. Wilson, "Local topographic wetness indices predict household malaria risk better than land-use and landcover in the western Kenya highlands," Malaria Journal, vol. 9, no. 1 , article no. $328,2010$.

[58] O. Kenea, M. Balkew, and T. Gebre-Michael, "Environmental factors associated with larval habitats of anopheline mosquitoes (diptera: Culicidae) in irrigation and major drainage areas in the middle course of the rift valley, central ethiopia," Journal of Vector Borne Diseases, vol. 48, no. 2, pp. 85-92, 2011.

[59] Y. Do, H. A. Kim, S. B. Kim et al., "Awareness and exploitation of wetland during the Joseon Dynasty," Journal of Wetlands Research, vol. 14, no. 3, pp. 329-340, 2012.

[60] B. Wielgosz, M. Mangheni, D. W. Tsegai, and C. Ringler, "Malaria and Agriculture," in A global view of the literature with a focus on the application of integrated pest and vector management in East Africa and Uganda, International Food Policy Research Institute, Washington DC, USA, 2012, IFPRI Discussion Paper 01232.

[61] T. Bousema, J. T. Griffin, R. W. Sauerwein et al., "Hitting hotspots: Spatial targeting of malaria for control and elimination," PLoS Medicine, vol. 9, no. 1, Article ID e1001165, 2012.

[62] C. J. Shiff, C. Stoyanov, C. Choobwe, A. Kamanga, and V. M. Mukonka, "Measuring malaria by passive case detection: A new perspective based on Zambian experience," Malaria Journal, vol. 12, no. 1, article no. 120, 2013.

[63] D. J. Kim, Joseon eui saengtaehwangyeongsa, Purunyeoksa, Seoul, South Korea, 2017.

[64] K. F. Austin, M. O. Bellinger, and P. Rana, "Anthropogenic forest loss and malaria prevalence: a comparative examination of the causes and disease consequences of deforestation in developing nations," AIMS Environmental Science, vol. 4, no. 2, pp. 217-231, 2017. 
[65] D. E. Norris, "Mosquito-borne Diseases as a Consequence of Land Use Change," EcoHealth, vol. 1, no. 1, pp. 19-24, 2004.

[66] S. L. Lewis and M. A. Maslin, "Defining the Anthropocene," Nature, vol. 519, no. 7542, pp. 171-180, 2015.

[67] P. Reiter, "Climate change and mosquito-borne disease: Knowing the horse before hitching the cart," Revue Scientifique et Technique de l'OIE, vol. 27, no. 2, pp. 383-398, 2008.

[68] W. H. Wernsdorfer and I. McGregor, Malaria: Principles and Practice of Malariology, Churchill Livingstone, Edinburgh, Scotland, 1988.

[69] S. C. Oaks, V. S. Mitchell, G. W. Pearson et al., Malaria: Obstacles and Opportunities, National Academy Press, Washington, DC, USA, 1991.

[70] J. A. Najera, "Malaria Control: Achievements, Problems and Strategies," Parassitologia, vol. 43, no. 1-2, pp. 1-89, 2001.

[71] J. A. Patz, P. Daszak, G. M. Tabor et al., "Unhealthy landscapes: Policy recommendations on land use change and infectious disease emergence," Environmental Health Perspectives, vol. 112, no. 10, pp. 1092-1098, 2004.

[72] R. M. Packard, The Making of a Tropical Disease: A Short History of Malaria, Johns Hopkins University Press, Baltimore, US, 2007.

[73] National Institute of Korean History, Hanguk Munhwasa, National Institute of Korean History, Gwacheon, South Korea, 2009.

[74] J. S. Yeom, "Construction of irrigation facilities in Hwaseongbu and management of Dunjeon in the late 18th century," Nongeobsayeongu, vol. 9, no. 1, 2010.

[75] J. S. Yeom, “The agricultural techniques and irrigation facilities in the medieval age-early modern age," Journal of Central Institute of Cultural Heritage, vol. 10, pp. 99-151, 2012.

[76] C. S. Song, "17, 18 Segi shinjeongaegan eui hwakdae wa gyeongyeongheyongtae," Hanguksaron, vol. 12, pp. 231-304, 1985, Dept. of Korean History, Seoul National University.

[77] J. S. Yeom, "Reclamation of river islands at lower Daedong river and transition of Gungbangjeon in the Late Joseon Dynasty," Gyujanggak, vol. 37, pp. 101-130, 2010.

[78] Y. J. Kim, A review for diffusion of rice transplantation and irrigation system during latter period of the Chosun Era [Master, thesis], Inha University, Incheon, South Korea, 2001.

[79] I.-S. Yeo, "U.S. military administration's malaria control activities (1945-1948)," Korean Journal of Medical History, vol. 24, no. 1, pp. 35-65, 2015.

[80] C.-Y. Jung, "Regional characteristics of Cheon during the Late Choson Era as seen through the Yojitoso," Journal of the Korean Geographical Society, vol. 43, no. 4, pp. 620-637, 2008 (Korean).

[81] C. Y. Chow, "Arthropods of public health importance in Korea," Korean Journal of Entomology, vol. 3, no. 1, pp. 43-44, 1973.

[82] L. Huldén, L. Huldén, and K. Heliövaara, "Endemic malaria: An 'indoor' disease in northern Europe. Historical data analysed," Malaria Journal, vol. 25, no. 4, 2005.

[83] L. Hulden and L. Hulden, "The decline of malaria in Finland The impact of the vector and social variables," Malaria Journal, vol. 8, no. 1, article no. 94, 2009.

[84] J. de Zulueta, "Malaria and ecosystems: from prehistory to posteradication.”, Parassitologia, vol. 36, no. 1-2, pp. 7-15, 1994.

[85] J. L. Gallup and J. D. Sachs, "The economic burden of malaria," The American Journal of Tropical Medicine and Hygiene, vol. 64, no. 1-2, pp. 85-96, 2001.
[86] R. I. Chima, C. A. Goodman, and A. Mills, "The economic impact of malaria in Africa: A critical review of the evidence," Health Policy, vol. 63, no. 1, pp. 17-36, 2003.

[87] Y.-K. Choi, K.-M. Choi, M.-H. Park et al., "Rapid dissemination of newly introduced Plasmodium vivax genotypes in South Korea," The American Journal of Tropical Medicine and Hygiene, vol. 82, no. 3, pp. 426-432, 2010.

[88] C. A. Guerra, S. I. Hay, L. S. Lucioparedes et al., "Assembling a global database of malaria parasite prevalence for the Malaria Atlas Project," Malaria Journal, vol. 6, article no. 17, 2007.

[89] J. W. Park, T. A. Klein, H. C. Lee et al., "Vivax malaria: A continuing health threat to the Republic of Korea," The American Journal of Tropical Medicine and Hygiene, vol. 69, pp. 159-167, 2003.

[90] H. Honma, J.-Y. Kim, N. M. Q. Palacpac et al., "Recent increase of genetic diversity in Plasmodium vivax population in the Republic of Korea," Malaria Journal, vol. 10, article no. 257, 2011.

[91] H.-L. Ju, J.-M. Kang, S.-U. Moon et al., "Genetic diversity and natural selection of Duffy binding protein of Plasmodium vivax Korean isolates," Acta Tropica, vol. 125, no. 1, pp. 67-74, 2013.

[92] J. W. Barnwell, M. E. Nichols, and P. Rubinstein, "In vitro evaluation of the role of the Duffy blood group in erythrocyte invasion by Plasmodium vivax," The Journal of Experimental Medicine, vol. 169, no. 5, pp. 1795-1802, 1989.

[93] J. H. Adams, B. K. L. Sim, S. A. Dolan, X. Fang, D. C. Kaslow, and L. H. Miller, "A family of erythrocyte binding proteins of malaria parasites," Proceedings of the National Acadamy of Sciences of the United States of America, vol. 89, no. 15, pp. 7085-7089, 1992.

[94] A. A. Holder, J. A. Guevara Patino, and C. Uthaipibull, "Merozoite surface protein 1 , immune evasion, and vaccines against asexual blood stage malaria," Parasitologia, vol. 41, pp. 409-414, 1999.

[95] S. P. Wertheimer and J. W. Barnwell, "Plasmodium vivax interaction with the human Duffy blood group glycoprotein: Identification of a parasite receptor-like protein," Experimental Parasitology emphasizes, vol. 69, no. 3, pp. 340-350, 1989.

[96] R. Horuk, C. E. Chitnis, W. C. Darbonne et al., "A receptor for the malarial parasite Plasmodium vivax: The erythrocyte chemokine receptor," Science, vol. 261, no. 5125, pp. 1182-1184, 1993.

[97] J.-M. Kang, H.-L. Ju, Y.-M. Kang et al., "Genetic polymorphism and natural selection in the C-terminal $42 \mathrm{kDa}$ region of merozoite surface protein-1 among Plasmodium vivax Korean isolates," Malaria Journal, vol. 11, article no. 206, 2012.

[98] M. Arévalo-Herrera and S. Herrera, "Plasmodium vivax malaria vaccine development," Molecular Immunology, vol. 38, no. 6, pp. 443-455, 2001.

[99] A. A. Holder, "Malaria vaccines: Where next?" PLoS Pathogens, vol. 5, no. 10, Article ID e1000638, 2009.

[100] M. C. Bruce, M. R. Galinski, J. W. Barnwell, G. Snounou, and K. P. Day, "Polymorphism at the merozoite surface protein$3 \alpha$ locus of Plasmodium vivax: global and local diversity," The American Journal of Tropical Medicine and Hygiene, vol. 61, no. 4, pp. 518-525, 1999.

[101] J. C. Rayner, V. Corredor, D. Feldman et al., "Extensive polymorphism in the Plasmodium vivax merozoite surface coat protein MSP-3 $\alpha$ is limited to specific domains," Parasitology, vol. 125, no. 5, pp. 393-405, 2002.

[102] M. C. Leclerc, C. Gauthier, L. Villegas, and L. Urdaneta, "Genetic diversity of merozoite surface protein-1 gene of Plasmodium vivax isolates in mining villages of Venezuela (Bolivar State)," Acta Tropica, vol. 95, no. 1, pp. 26-32, 2005. 
[103] J.-Y. Chai, Y.-K. Park, S.-M. Guk et al., "A trial for a DNA diagnosis of Plasmodium vivax malaria recently reemerging in the republic of korea using microtiter plate hybridization assay," The American Journal of Tropical Medicine and Hygiene, vol. 63, no. 1-2, pp. 80-84, 2000.

[104] C. S. Lim, S. H. Kim, S. I. Kwon, J.-W. Song, K.-J. Song, and K. N. Lee, "Analysis of Plasmodium vivax merozoite surface protein-1 gene sequences from resurgent Korean isolates," The American Journal of Tropical Medicine and Hygiene, vol. 62, no. 2, pp. 261$265,2000$.

[105] C. S. Lim, Y. K. Kim, K. N. Lee et al., “ The analysis of circumsporozoite-protein gene sequences from South Korean isolates of ", Annals of Tropical Medicine \& Parasitology, vol. 95, no. 3, pp. 229-235, 2016.

[106] W. G. Kho, J. Y. Chung, E. J. Sim, D. W. Kim, and W. C. Chung, "Analysis of polymorphic regions of Plasmodium vivax Duffy binding protein of Korean isolates.", The Korean Journal of Parasitology, vol. 39, no. 2, pp. 143-150, 2001.

[107] J.-Y. Chung, E.-H. Chun, J.-H. Chun, and W.-G. Kho, "Analysis of the Plasmodium vivax apical membrane antigen-1 gene from re-emerging Korean isolates," Parasitology Research, vol. 90, no. 4, pp. 325-329, 2003.

[108] D. H. Nam, J. S. Oh, M. H. Nam et al., "Emergence of new alleles of the MSP-3alpha gene in Plasmodium vivax isolates from Korea," The American Journal of Tropical Medicine and Hygiene, vol. 82, no. 4, pp. 522-524, 2010.

[109] D. E. Neafsey, K. Galinsky, R. H. Y. Jiang et al., "The malaria parasite Plasmodium vivax exhibits greater genetic diversity than Plasmodium falciparum," Nature Genetics, vol. 44, no. 9, pp. 1046-1050, 2012.

[110] P. Orjuela-Sánchez, J. M. Sá, M. C. C. Brandi et al., "Higher microsatellite diversity in Plasmodium vivax than in sympatric Plasmodium falciparum populations in Pursat, Western Cambodia," Experimental Parasitology emphasizes, vol. 134, no. 3, pp. 318-326, 2013.

[111] W. Liu, Y. Li, K. S. Shaw et al., "African origin of the malaria parasite Plasmodium vivax," Nature Communications, vol. 5, p. 3346, 2014.

[112] A. E. Barry, A. Waltmann, C. Koepfli, C. Barnadas, and I. Mueller, "Uncovering the transmission dynamics of Plasmodium vivax using population genetics," Pathogens and Global Health, vol. 109, no. 3, pp. 142-152, 2015.

[113] M. Iwagami, S.-Y. Hwang, S.-H. Kim et al., "Microsatellite DNA Analysis Revealed a Drastic Genetic Change of Plasmodium vivax Population in the Republic of Korea During 2002 and 2003," PLOS Neglected Tropical Diseases, vol. 7, no. 10, Article ID e2522, 2013.

[114] K. Tamura, G. Stecher, D. Peterson, A. Filipski, and S. Kumar, "MEGA6: Molecular Evolutionary Genetics Analysis version 6.0," Molecular Biology and Evolution, vol. 30, no. 12, pp. 27252729, 2013.

[115] B. G. Hall, "Building phylogenetic trees from molecular data with MEGA," Molecular Biology and Evolution, vol. 30, no. 5, pp. 1229-1235, 2013.

[116] L. Cui, A. A. Escalante, M. Imwong, and G. Snounou, "The genetic diversity of Plasmodium vivax populations," Trends in Parasitology, vol. 19, no. 5, pp. 220-226, 2003.

[117] Y. S. Kim, M. J. Kim, and J. H. Hong, “The Scientific and Ethical Background of the Invasive Studies on the Korean Mummies of the Joseon Dynasty," Asian Journal of Paleopathology, vol. 1, pp. 5-11, 2017.
[118] I. S. Lee, E.-J. Lee, J. B. Park et al., "Acute traumatic death of a 17 th century general based on examination of mummified remains found in Korea," Annals of Anatomy, vol. 191, no. 3, pp. 309-320, 2009.

[119] D. H. Shin, C. S. Oh, S. J. Lee et al., "Ectopic paragonimiasis from 400-year-old female mummy of Korea," Journal of Archaeological Science, vol. 39, no. 4, pp. 1103-1110, 2012.

[120] D. H. Shin, C. S. Oh, H. J. Lee et al., "Ancient DNA analysis on Clonorchis sinensis eggs remained in samples from medieval Korean mummy," Journal of Archaeological Science, vol. 40, no. 1, pp. 211-216, 2013.

[121] E.-J. Lee, C. S. Oh, S. G. Yim et al., "Collaboration of Archaeologists, Historians and Bioarchaeologists During Removal of Clothing from Korean Mummy of Joseon Dynasty," International Journal of Historical Archaeology, vol. 17, no. 1, pp. 94-118, 2013.

[122] M. Seo, A. Araujo, K. Reinhard, J. Y. Chai, and D. H. Shin, "Paleoparasitological studies on mummies of the Joseon Dynasty, Korea," The Korean Journal of Parasitology, vol. 52, no. 3, pp. 235-242, 2014.

[123] Y.-S. Kim, I. S. Lee, C. S. Oh, M. J. Kim, S. C. Cha, and D. H. Shin, "Calcified pulmonary nodules identified in a 350-year-oldjoseon mummy: The first report on ancient pulmonary tuberculosis from archaeologically obtained pre-modern Korean samples," Journal of Korean Medical Science, vol. 31, no. 1, pp. 147-151, 2016.

[124] J. Keiser, M. C. De Castro, M. F. Maltese et al., "Effect of irrigation and large dams on the burden of malaria on a global and regional scale," The American Journal of Tropical Medicine and Hygiene, vol. 72, no. 4, pp. 392-406, 2005.

[125] K. Asenso-Okyere, F. A. Asante, J. Tarekegn et al., "The Linkages between Agriculture and Malaria. Issues for Policy, Research and Capacity Strengthening," in Proceedings of the IFPRI Discussion Paper 00861, International Food Policy Research Institute, Washington DC, USA, 2009.

[126] S. S. Myers, L. Gaffikin, C. D. Golden et al., "Human health impacts of ecosystem alteration," Proceedings of the National Acadamy of Sciences of the United States of America, vol. 110, no. 47, pp. 18753-18760, 2013.

[127] G. Z. Laporta, P. I. K. L. D. Prado, R. A. Kraenkel, R. M. Coutinho, and M. A. M. Sallum, "Biodiversity Can Help Prevent Malaria Outbreaks in Tropical Forests," PLOS Neglected Tropical Diseases, vol. 7, no. 3, Article ID e2139, 2013.

[128] J. A. Carney, Black Rice: The African Origins of Rice Cultivation in the Americas, Harvard University Press, Cambridge, MA, USA, 2001.

[129] J. N. Ijumba and S. W. Lindsay, "Impact of irrigation on malaria in Africa: Paddies paradox," Medical and Veterinary Entomology, vol. 15, no. 1, pp. 1-11, 2001.

[130] E. Klinkenberg, W. Takken, F. Huibers, and Y. T. Touré, “The phenology of malaria mosquitoes in irrigated rice fields in Mali," Acta Tropica, vol. 85, no. 1, pp. 71-82, 2003.

[131] G. Dolo, O. J. T. Briët, A. Dao et al., "Malaria transmission in relation to rice cultivation in the irrigated Sahel of Mali," Acta Tropica, vol. 89, no. 2, pp. 147-159, 2004.

[132] P. N. Ng’ang’a, J. Shililu, G. Jayasinghe et al., "Malaria vector control practices in an irrigated rice agro-ecosystem in central Kenya and implications for malaria control," Malaria Journal, vol. 7, article no. 146, 2008.

[133] J. M. Mwangangi, J. Shililu, E. J. Muturi et al., "Anopheles larval abundance and diversity in three rice agro-village complexes 
Mwea irrigation scheme, central Kenya," Malaria Journal, vol. 9, no. 1, article no. 228, 2010.

[134] J. A. Patz, T. K. Graczyk, N. Geller, and A. Y. Vittor, "Effects of environmental change on emerging parasitic diseases," International Journal for Parasitology, vol. 30, no. 12-13, pp. 1395-1405, 2000.

[135] S. Munga, N. Minakawa, G. Zhou et al., "Association between land cover and habitat productivity of malaria vectors in western Kenyan highlands," The American Journal of Tropical Medicine and Hygiene, vol. 74, no. 1, pp. 69-75, 2006.

[136] A. Y. Vittor, R. H. Gilman, J. Tielsch et al., "The effect of deforestation on the human-biting rate of Anopheles darlingi, the primary vector of Falciparum malaria in the Peruvian Amazon," The American Journal of Tropical Medicine and Hygiene, vol. 74, no. 1, pp. 3-11, 2006.

[137] J. Yasuoka and R. Levins, "Impact of deforestation and agricultural development on anopheline ecology and malaria epidemiology," The American Journal of Tropical Medicine and Hygiene, vol. 76, no. 3, pp. 450-460, 2007.

[138] K. C. Ernst, K. A. Lindblade, D. Koech et al., "Environmental, socio-demographic and behavioural determinants of malaria risk in the western Kenyan highlands: A case-control study," Tropical Medicine \& International Health, vol. 14, no. 10, pp. 1258-1265, 2009.

[139] A. Y. Vittor, W. Pan, R. H. Gilman et al., "Linking deforestation to malaria in the Amazon: characterization of the breeding habitat of the principal malaria vector, Anopheles darlingi," The American Journal of Tropical Medicine and Hygiene, vol. 81, no. 1, pp. 5-12, 2009.

[140] E. Teferi, S. Uhlenbrook, W. Bewket, J. Wenninger, and B. Simane, "The use of remote sensing to quantify wetland loss in the Choke Mountain range, Upper Blue Nile basin, Ethiopia," Hydrology and Earth System Sciences, vol. 14, no. 12, pp. 24152428, 2010.

[141] B. H. Manh, A. C. A. Clements, N. Q. Thieu et al., "Social and environmental determinants of malaria in space and time in Viet Nam," International Journal for Parasitology, vol. 41, no. 1, pp. 109-116, 2011.

[142] A. Midekisa, G. B. Senay, and M. C. Wimberly, "Multisensor earth observations to characterize wetlands and malaria epidemiology in Ethiopia," Water Resources Research, vol. 50, no. 11, pp. 8791-8806, 2014.

[143] W. Hanandita and G. Tampubolon, "Geography and social distribution of malaria in Indonesian Papua: A cross-sectional study," International Journal of Health Geographics, vol. 15, no. 1, article no. 13, 2016.

[144] X. Wang, G. Zhou, D. Zhong et al., "Life-table studies revealed significant effects of deforestation on the development and survivorship of Anopheles minimus larvae," Parasites \& Vectors, vol. 9, no. 1, article no. 323, 2016.

[145] A. K. Jorgenson and T. J. Burns, "Effects of rural and urban population dynamics and national development on deforestation in less-developed countries, 1990-2000," Sociological Inquiry, vol. 77, no. 3, pp. 460-482, 2007.

[146] T. Bensel, "Fuelwood, deforestation, and land degradation: 10 years of evidence from Cebu province, the Philippines," Land Degradation \& Development, vol. 19, no. 6, pp. 587-605, 2008.

[147] K. F. Austin, M. D. Noble, and M. T. Mejia, "Gendered vulnerabilities to a neglected disease: A comparative investigation of the effect of women's legal economic rights and social status on malaria rates," International Journal of Comparative Sociology, vol. 55, no. 3, pp. 204-228, 2014. 


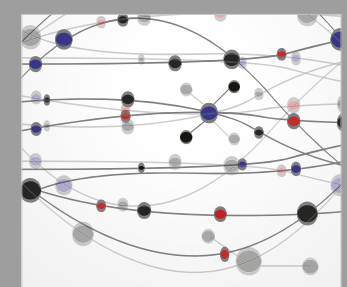

The Scientific World Journal
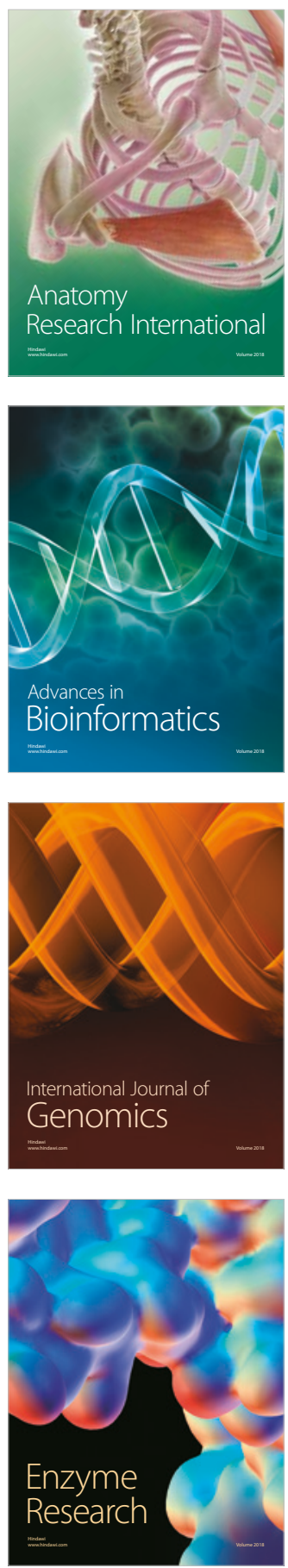
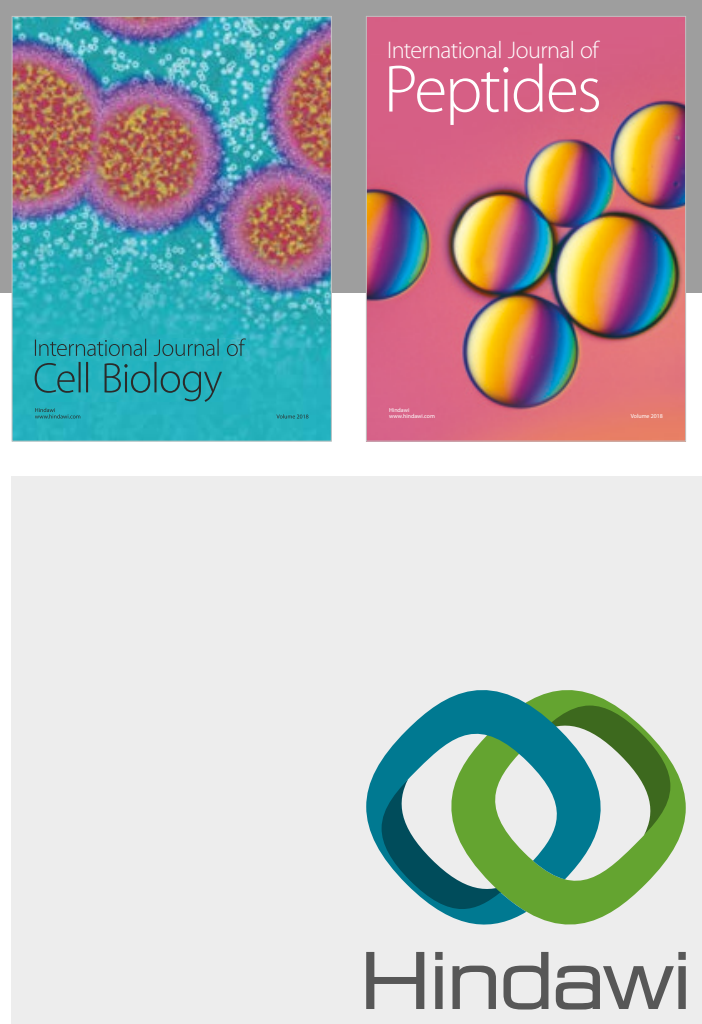

Submit your manuscripts at

www.hindawi.com
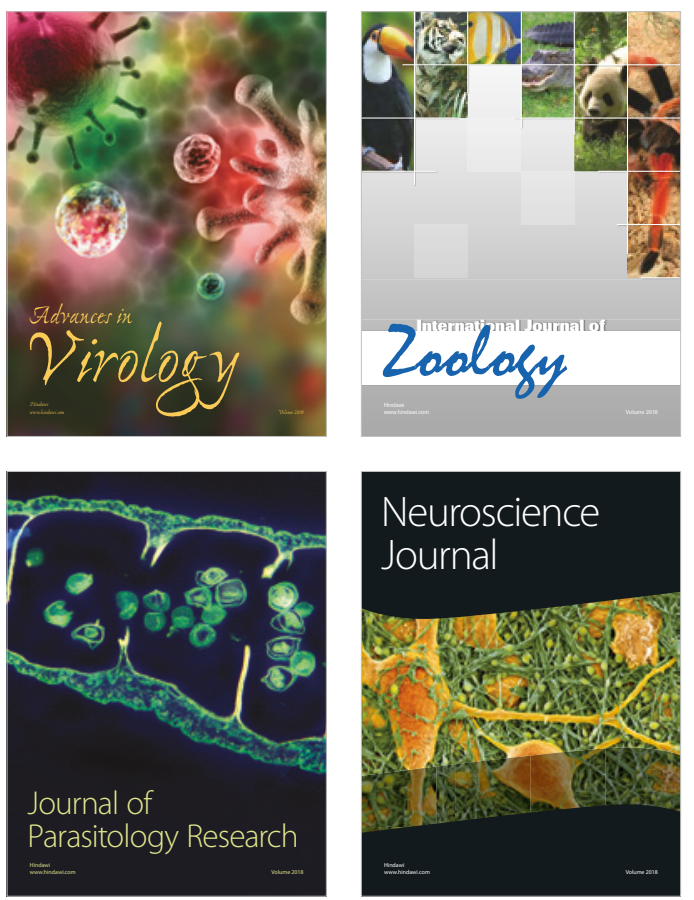
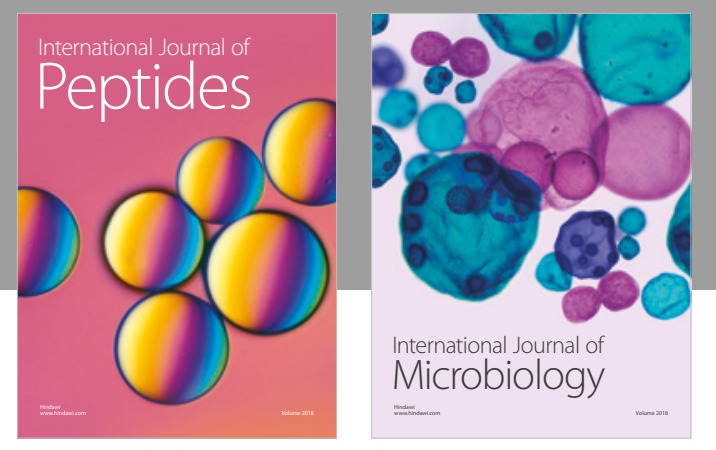

nternational Journal of Microbiology
Journal of
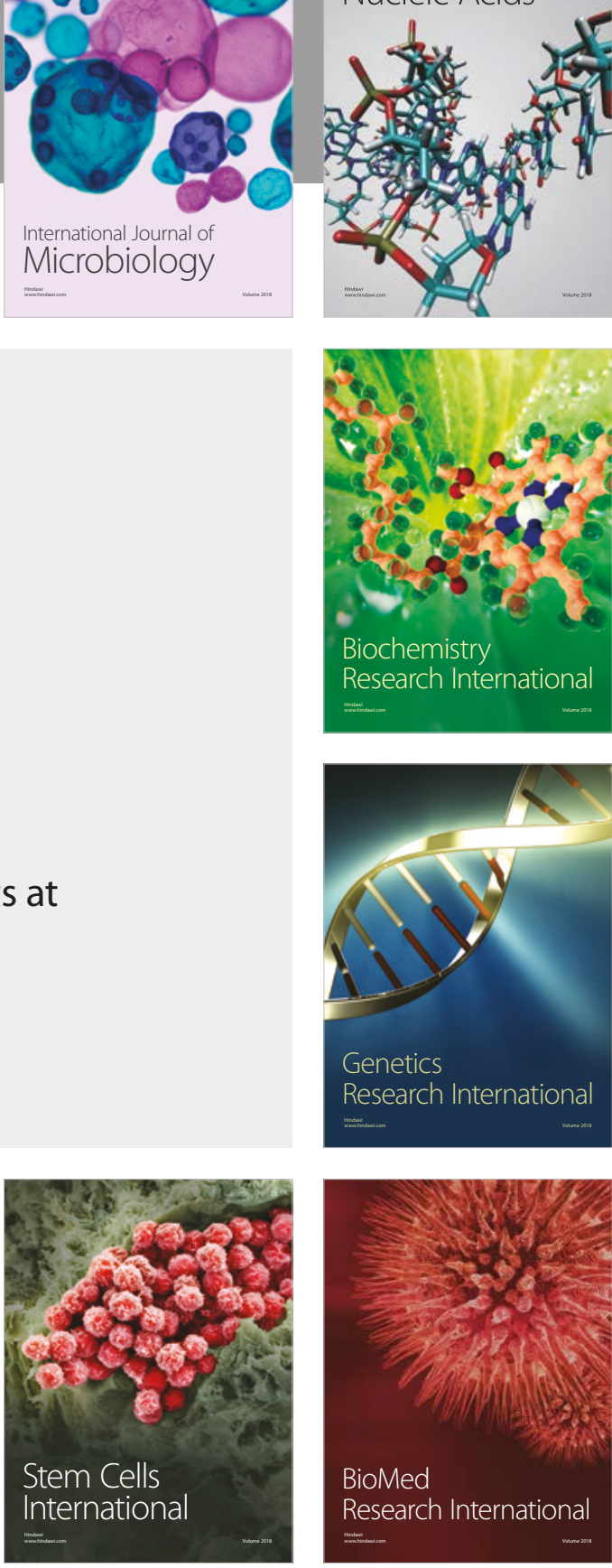
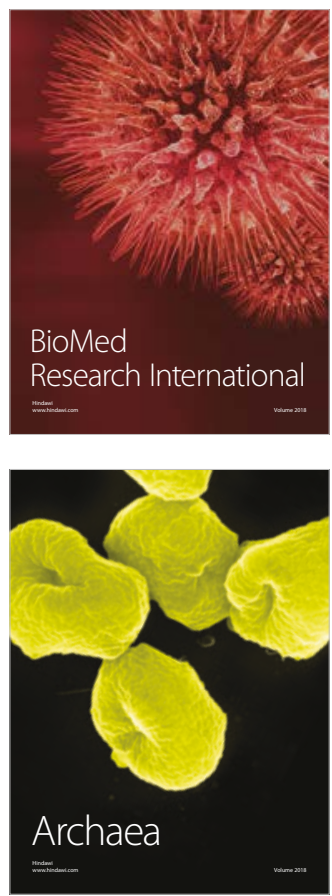